Note for Readers: This article is the version before print. Readers are therefore advised to visit the journal pages if you wish to cite the correct page and reference.

\title{
See below:
}

Padma Anagol, 'Languages of Injustice: The Culture Of 'Prize-Giving' And Information Gathering on Female Infanticide in Nineteenth-Century India', in Gender and Justice in South Asia, 1772-2013 in Cultural and Social History, Padma Anagol, (ed.). Special Issue, 4:4 (Aug. 2017), pp.429-

445. https://doi.org/10.1080/14780038.2017.1329124

\section{LANGUAGES OF INJUSTICE: THE CULTURE OF 'PRIZE-GIVING' AND INFORMATION GATHERING ON FEMALE INFANTICIDE IN NINETEENTH- CENTURY INDIA}

\section{INTRODUCTION}

In the past three decades, new imperial histories have made impressive advances in understanding the nature and function of colonial knowledge about India. From the beginning of their rule, the British produced bodies of knowledge about Indian society that sought to order and make sense of what they encountered in the drive to provide good government. The attempt to categorize Indians into groups and dictate how they should behave, along lines which Britons perceived as true and accurate is now widely recognised in the wider cultural history of empire as the 'civilising mission'. ${ }^{1}$ In the drive to appear as a progressivist government, the Raj launched one of the most formidable operations in the latter half of the $18^{\text {th }}$ century that involved the discovery, reform-minded development and elimination programmes targeted against the custom of female infanticide found in pockets of Northern and Western India.

\section{THE LONG HISTORIOGRAPHY ON FEMALE INFANTICIDE}

An overarching debate in the long historiography on female infanticide in India is polarised between reading British actions to socially reform India as based on genuine humanitarian concern or as undiluted imperialistic motives. Kanti Pakrasi and Lalita Panigrahi plotted the development of British policy by presenting the successful suppression of female infanticide by the 'benevolent' British government that was driven by 'humanitarian zeal'. ${ }^{2}$ These early contributions to the understanding of the reform of female infanticide were written in the 
1970s, well before Edward Said launched his damning criticism of the West's imperial will to rule through the creation of a system of absolute power which he termed as 'Orientalism'. Following poststructuralist models of deconstruction of official discourses, cultural and gender scholarship have challenged the one-dimensional approaches of earlier historians. Some scholars have argued that on the back of the 'discovery' of female infanticide rode the moral imperative of imperialism - the 'civilising mission'- and in the words of Veena Oldenburg, 'it served the most compelling justification, both to the company itself and to a critical public in England, for the conquest, pillage and domination of India's people and the destruction of their local cultures.' ${ }^{3}$

Another key debate in Indian social history is the colonizer's lackadaisical attitude towards the welfare of the subject being reformed. Alice Clark has concluded that 'a greater concern for keeping revenues on the increase than for the welfare of women and children was clearly evident' in the British suppression of female infanticide. ${ }^{4}$ Clark's interpretation suggests that the British government's discourse on 'humanitarian concern' for the victim of the custom of female infanticide was merely rhetoric to mask their own economic interests in India. Other scholars have outlined the pressures on Indian societies in practising this custom by analysing sociological imperatives of 'pride' and 'honour' of such communities which forced them into infant killing; or of issues of upward social mobility that made it impossible for Rajput communities to keep their female children alive. Postcolonial scholarship embedded in feminist theory has revisited and revised received wisdom on the practice of female infanticide in India. Rashmi Bhatnagar and her colleagues have argued persuasively that foeticide (selective killing of female foetus) in post-colonial India is a continuation of violence against girl-children and women derived from the discourses of colonial India. ${ }^{5}$ Another important feminist intervention published in 2002 analysed infanticidal women's petitions to the British government and through a woman-centred perspective showed the rich and multi-layered reasons that prompted women to play a part in the decision to kill infants of either sex. ${ }^{6}$ Malavika Kasturi and Radhika Singha shifted the focus of the debate to take on the legal perspective by concentrating specifically on the Female Infanticide Act of $1870 .^{7}$ Kasturi exposed it as a repressive measure, while Singha focused on the registration system that was put in place and how it served British interests outside of the reform itself through the creation of a surveillance system. Taken together, works from 1990s onwards have added important social, legal, gender and cultural angles to the historiography on female infanticide 
by a rigorous questioning of seemingly accepted 'facts' about the practice of female infanticide.

\section{APPROACH AND METHODOLOGY: PRIZE CULTURES AS AN INSTRUMENT OF RULE}

In this study I am shifting the focus to the neglected area of information gathering, and argue that the culture of prize-giving instituted by the Company government acted as an instrument of rule. In the adoption of this methodological approach, the historian's gaze then shifts to the Indian elites who were drawn into the 'discovery' of the crime of female infanticide. In parts of western India, the practice of female infanticide was endemic enough to slip into the official discourse as 'custom'. When the Company officials 'discovered' the crime - they were up against formidable forces as it was often reported that female infanticide took place in the heart of the domestic interiors of the Indian home called the 'zenana' reputed to be inaccessible to men. In the broader historiography on colonial knowledge arguments have been made by scholars that complex surveillance techniques were used to figure out the crime. Chris Bayly, for example, has demonstrated the role of local officials especially at the lower end of the administrative scale such as village constables hired to spy on the communities practising this custom. 'Native informants' he has argued cogently were integrated into an elaborate network of surveillance that fed into a larger British intelligence frame in order to rule more effectively. ${ }^{8}$ The Parliamentary Papers and correspondence of Company official embedded in the Selections from the Records constitute a major archival source for this topic that contain formidable amounts of material in the form of settlement and census reports - some specially commissioned and some literature produced by Indian elite men - often dubbed as the 'respectable' notables of their own community and adopted as 'natural leaders' of their society by the Raj..

In recent years, the cultures of prizes, awards, bounty schemes and government sponsored initiatives have received wide attention from cultural historians keen on noting the functions and effects of the 'economy of prestige' in the development of societies over the centuries. ${ }^{10}$ This study takes James English's probing statement that 'Prizes have always been of fundamental importance to the institutional (sic) machinery of cultural legitimacy and authority' as a starting point to examine prize essays in India. ${ }^{11}$ Within the cultural economy of a nation, 'prizes' continue to be the most bankable and legitimate cultural worth of an author and hence, national bureaucracies in the historical past, from Cosimo and Richelieu's 
Academies onwards, have regarded prizes as valuable assets in the fields of national culture, maintaining and certifying value in western societies. The cultural economy of 'prizes' was then imported into the governance of colonies and became part of the template that governed the later 'civilising mission' programs of the British government in the colonies. Upholding cultural standards by means of rebuke or reward was governed by the prize cultures to reward those who met British standards of morality, and to mete out judgments against those who transgressed or infringed their laws of justice. I wish to examine here the function of the culture of prize-giving. Was it just a benign exercise of addressing and transforming a 'custom' (as female infanticide was understood by natives) into a 'crime' or incorporating Indians as 'collaborators' in the civilising mission? Was prize-giving just a mere conduit for educating the ignorant? What did it mean to Indian reformers who joined this hunt? Social and political historians of female infanticide have suggested that British policy on female infanticide moved unevenly from pacification to coercion and sometimes back again in the years preceding the imposition of the punitive Female Infanticide Act in 1870. Two central questions about prize-essays are particularly relevant. Firstly, what was the role of social reformers who participated in the prize cultures, especially in adopting European literary forms even whilst the 'essay' was slowly forming into a major heuristic device? Secondly, how did the prize-giving culture contribute to political and social policy on the subject of female infanticide as an instrument of British rule?

\section{THE GENEALOGY OF PRIZE CULTURES ON FEMALE INFANTICIDE}

The historical literature on female infanticide lists four stages in the long trajectory of eradication efforts by the British in the eighteenth and nineteenth centuries. The palliative measures including the prize cultures fall roughly in the third and fourth stage of the measures to eradicate the practice of female infanticide, namely the $1830 \mathrm{~s}$ and early $1840 \mathrm{~s}^{12}$ From the late 1830s onwards the British looked for a permanent solution to the problem of female infanticide through the diffusion of education and knowledge amongst indigenous communities. It was hoped that this would make the guilty communities reassess their commitment to the practice. In Kathiawar, (western India) under the authority of Mr. J.P. Willoughby, the British Political Agent, administrative measures against female infanticide were increased. This was deemed necessary because previous anti-infanticide declarations made by the community heads to Colonel Alexander Walker, Resident at Baroda had failed to effectively reduce the prevalence of female infanticide. ${ }^{13}$ Willoughby was intent on the 
suppression of this practice, and declared the necessity of a census to be conducted of the entire Jadeja community. It was during this period we see the full blown surveillance schemes in operation.

It is worthwhile discussing some of the policies introduced by Willoughby as his methods for the suppression of female infanticide have been considered as novel by social historians working on Western India. He introduced a system of rewards for informers and a scale of fines for the guilty. He even went as far as threatening the Jadeja chiefs with the prospect of losing the sovereignty of their individual provinces and the guilty now were brought in front of the Criminal Court of Justice set up in Kathiawar. ${ }^{14}$ In the very first case where infanticide was proven in the case of Jhareja Soorajee, Chief of Rajkot, 'justice', argued Willoughby, had to be 'tempered with mercy' and it would serve British interests better to 'enlist the feelings of the community on our side,' and that British sense of justice had to take into account indigenous ideas of justness and their notions of penalties. Explaining his standpoint in some detail, he reasoned that severe penalties alone might simply be, 'injurious to our future efforts to effect the complete extinction of the practice'. ${ }^{15}$ Willoughby put into place a system of rewards from the Infanticide Fund which had been set up in 1825 in Western India. The Fund pooled the monies secured from fines imposed on erring Jhareja Chiefs. Whenever a chief saved his daughter from an ignoble death he was given gifts of money or clothes. Willoughby also introduced a hierarchy of fines depending on the ranking of the chief whilst the gifts increased with the numbers of daughters saved by them. ${ }^{16}$ Willoughby and his illustrious predecessors too were guided by Benthamite notions of justice that included the adage that the object of punishment was not to inflict physical pain out of vengeful motivations, but to assist the state's objective of prevention of crime.

However, by the end of the 1830 s, some British administrators felt that this hard-line approach alone would not solve the problem of female infanticide. It was seen as tackling the effect of female infanticide rather than addressing the actual causes of the practice. It is from this perspective that James Erskine, who took over from Willoughby as Political Agent in 1836, declared that Soorajee was considered a "martyr" rather than a justly punished culprit"' not just by the Jharejas but, by the entire Rajput community. He feared that such coercive acts would 'render the Government contemptible, and, besides paralyse and perhaps destroy the Court of Justice, which had been of such benefit to the peace of the Country.' Soon, Erskine replaced the policy of punishment with the soft approach of 'education, mental improvement, and moral amelioration of the mass of the people'. ${ }^{17}$ In this report he also 
mentioned that the former Governor of Bombay, Mountstuart Elphinstone had put into place ameliorative measures only in the Bombay Presidency and Deccan but such palliative measures had been overlooked in Gujarat which he intended to correct. Towards the attainment of these goals he started wholesale translations of apparently salubrious moral tracts from England and translations of Hindu scriptures from Sanskrit to Gujarati for dissemination amongst the Gujarati communities. ${ }^{18}$ Erskine's report made it abundantly clear to the colonial government that his predecessor's policies were too harsh and won no friends amongst the Jhareja and Rajput communities. ${ }^{19}$

How was the shift made from coercion to persuasion? One strand of the indirect approach of the colonial govt. was the institution of a prize culture. It included an elaborate apparatus, starting with the propaganda measure of soliciting the production of the best essays on female infanticide, and once the prize winners were announced it led to the wholesale printing of 'prize essays' in the form of booklets for distribution amongst infanticidal communities. By focussing on such specific instruments of rule, I do not intend to make them appear more significant than other surveillance techniques. In fact, the Bombay government issued clear directives regarding the implementation of ameliorative measures to run in tandem with the punitive ones. It is important to stress, however, that the softer technique of the prize culture had several outcomes which apart from showing the invasive nature of cultural imperialism had damaging consequences for women of these communities. These essays are important historical sources that can be used to gain an insight into the mind-set of the British since they decided which essays would be published and edited them accordingly. At the same time, these essays provide insights into the contours of Indian patriarchy allowing the historian of gender to trace the strands within a discourse that allowed for the tightening of patriarchal practices. The British attempt to win over the hearts and minds of Indians are illustrated in the prize essays and how reform sought to remove the perceived chief causes of female infanticide - 'pride and purse', by appealing to the moral conscience of the Kathiawar communities.

The following extract from a letter by Major Jacob, a British official based in Kathiawar, is representative of the mood in which these essay competitions emerged:

I feel strongly impressed with the necessity of a line of policy that shall strike at the heart, and consequently at the root of the disease, and afford a permanent remedy; ...It is true, that no immediate result can be expected from education; but the slow growth of its 
blessings is an argument for no time being lost in the attempt to impart them. We may save life by the census, but how can we protect it from misery and neglect afterwards? Whilst approving, therefore, of the present coercive system, I conceive that it should be looked on merely as a temporary expedient, and that it ought to be accompanied by healing and general measures, namely, an attempt to create a higher tone of moral feeling throughout the community generally... ${ }^{20}$

Further Captain Jacob pointed out that there was a surplus in the Infanticide Fund that could be judiciously expended for the cause of education by instituting a system of annual essay prize competitions in the vernacular language with attractive prize monies. Jacob was confident that this measure, 'would enlist the feelings of the rising generation against the crime' with the hope that '...the scholars of the Rajkot College might catch the spirit of emulation' and that soon the government might be able to dispense with 'at least, the harsh portions of the present coercive system, as the scaffolding is removed on completion of the building. ${ }^{21}$

In response, J.P. Willoughby ruled that the Bombay government had no objection to instituting an award scheme and that its expenses could be borne out of the Infanticide Fund. Kathiawar had no high schools worthy of mention at the time, therefore the prizes were diverted to the Bombay Native Education Society, where scholars of native elites could compete and the prizes could become 'objects of emulation' ${ }^{22}$ By 1820 s, western India was annexed to the East India Company but it was not yet settled long enough to inspire abject obedience from its subjects. Hence, the Political Agent, faced a formidable task in imposing the rule of law and outlawing female infanticide in a successful manner. Thus, it seems plausible that the competitions were inaugurated by the alien ruler as an exercise in inspiring confidence and appearing legitimate in front of its subjects. It was hoped by the Company government that attempting to circulate the moral message within the affected communities from the mouth of Indian elites may have more weight than if it were introduced purely by imperial administrators. The prize monies were substantial. The first prize was Rs.600 and the second Rs.400, as advertised in the Government Gazette on the $14^{\text {th }}$ September $1843 .{ }^{23}$

The first competition winner, announced in1844, was twenty-two year old 'Bhawoo Dajee' or more accurately spelled - Bhau Daji Lad as he was known in native circles. Daji 
was a visionary by all accounts, who was described as a 'founding Father of modern Bombay' due to his passionate involvement in the formation of the University of Bombay, the Victoria and Albert Museum and the Bombay Association, the precursor body to the founding of the Indian National Congress. ${ }^{24} \mathrm{He}$ was an assistant teacher at the prestigious Elphinstone institution when the notification went out announcing the competition. His biographers, who were themselves eminent Sanskrit scholars, say he was also well read in the Hindu scriptures and was a practitioner of Ayurvedic medicine. ${ }^{25}$ He later went on to become an allopathic physician, epitomising the imperial rhetoric that natives could rise rapidly through the ranks when they made efforts to collaborate with the government. Daji's prize essay was cited again and again within the social reform circles and it was this singular contribution that was upheld by dignitaries, government officials and western orientalist scholars in the $19^{\text {th }}$ and $20^{\text {th }}$ centuries..$^{26}$ Of the many appreciative obituaries published in leading newspapers after his death, the western world seemed obsessed with Daji's social reform initiatives in the form of the prize essay. This overshadowed his more original and striking contributions to colonial knowledge in the wider disciplines of archaeology, zoology, numismatics, botany, ancient history, and his proposed Ayurvedic cure for leprosy. Pakrasi asserts that Daji became 'a historical figure of contemporary times' after the prize was announced. ${ }^{27}$

The colonial government had judged the first competition a success and turned to instituting more prize competitions in other regions of India where they found the custom of female infanticide to be as endemic as it was in the region of western India. The regions of Punjab, Orissa and Benares, however, had widely differing set of circumstances that prompted female infanticide, and therefore, merit a separate study. The confines of this article have also prevailed upon me to focus on the essays submitted in the Western Indian prize competition. Here, I study the rejected essays alongside the winning essay of Bhau Daji which engaged vigorously with the practice of female infanticide amongst the Jadejas of the Western Indian regions of Kutch and Kathiawar (Gujarat). ${ }^{28}$

\section{THE SELECTION PROCESS: PRIZE ESSAYS AS EXEMPLARS OF THE AGE OF ENLIGHTENMENT}


The early colonial state harnessed the potential energies of talented young Indian men who were to become the local 'raiyees' (natural leaders) later through an incentive scheme of instituting 'prize essays' on the topic of female infanticide. This section queries the principles of selection, the motivations of the panel of judges, and how the merits and shortcomings of the essays themselves were considered on certain pre-defined criteria. The arguments used by the indigenous agents, the filtering process of the prize committees in deciding which essay had the most merits and which didn't, reveal interesting facets of this enterprise. The selection process - that is, what essay was selected and what was dropped out of this competition, it will be argued, depended on the imperial needs of rule which in turn was constructed on the Enlightenment ideals of science and reason over myth and superstition.

By the 1840s, when Bhau Daji entered the essay competition on female infanticide, James Mill's History of British India had convinced a whole generation of East India Company officials of the cultural inadequacies of India. The artistic achievements, religious moorings and complex legal systems of India had been dismissed as 'the rudest and weakest state of the human mind. ${ }^{29}$ The Selection Committee usually comprised of a missionary scholar and several officials of the Company who represented the educational sector such as Oriental Translators, Secretaries of the Bombay Education Society and members of the Board of Education. ${ }^{30}$ These learned men were guided by the idea that a new political and social order informed by the Enlightenment ideals of freedom and equality for all, founded, ostensibly, upon principles of human reason needed to be established in India.

The selection procedures, remarks and comments of the members in charge of deciding the prize reveals an interesting set of pre-judged and pre-determined concepts and prejudices afloat in the official discourse. One of the competitors who lost out to Daji was an esteemed Brahmin priest, Raghunath Parwati Shastri. Raghunath Shastri had written the essay in fluent Sanskrit. From his vast knowledge of Hindu scriptures, legends and classics, Shastri had provided numerous examples of how female infanticide was frowned upon severely by the Hindu Gods, and how even killing female demons evoked remorse in the hearts of morally upright Kings. The rationale for rejecting the essay was outlined as -'These stories, well-known to the natives, are sufficiently incongruous and grotesque to fall within the sphere of Hindu belief.' The essay was deemed 'unsuitable for publication' because it was 'entirely written on Hindu principles.' 31 The sentiment is resonant with Daniel Grey's 
findings that the most sensational 'customs' of early colonial India such as sati, thuggee and female infanticide were inexorably linked and "uniquely represented as 'Hindu' crimes," full of lethal violence and harm towards vulnerable groups such as women. ${ }^{32}$ This was not the first time that an essay by a Hindu priest arguing against female infanticide was rejected. Lancelot Wilkinson, a civil servant who had worked amongst the Rajputs of Central India, had tried the experiment of distributing tracts against female infanticide written by Hindu scholars in the 1830s. A Brahmin poet, Omkar Bhatta, had composed a stirring poem eloquently pleading against female infanticide by evoking Hindu scriptures in aiding his arguments. For want of a better or more 'suitable' tract, the Bombay government modified his arguments and then printed and distributed 700 copies of it. That Hinduism as a religious body condemned female infanticide was conveniently forgotten in the liberal western discourse of how the 'patronage of a Christian government' could not extend to supporting or preaching 'superstition or practise imposture, either directly or indirectly, even to promote the cause of humanity. ${ }^{33}$ The central axiom in the rejected essays was that India was not a dense or impenetrable mass resistant to all logical enquiry. In fact, both Raghunath and Omkar were elucidating the humanity of Hinduism and the rationality of Hindus in applying equality to life chances of both sexes. But as Uday Singh Mehta says so eloquently, 'Liberalism's strategy is to utilise "difference" to make universality conditional' and any call for political inclusion rested on the 'necessity of a complex set of individual and social indexes' or what Mehta terms as the 'strategy of civilizational infantilism'. ${ }^{34}$ The Hindu priest and poet's reasoning would not have allowed them to be included in a self-representation of India or Indian moral orders, in the drive towards the civilising mission of the Company government, hence the outright rejection of the first and the highly altered acceptance of the latter.

If we turn to Daji's essay, it is clear that he had adopted the Western discourse of subjecting his arguments to a rigorous mode of reasoning and substantiation. His tract started with a consideration of what several authoritative Hindu texts said about the crime of female infanticide (he quoted mainly the Bhagavata, Agni and Padma Puranas) and proceeded rapidly to a consideration of what other religions and their texts (Quran and Bible) said about murder of female infants. ${ }^{35}$ Orientalist scholarship, had by then legitimated the Vedas as the authentic fountain of Indian learning, dismissing the Puranas as myths, hence Malabari's hasty synopsis of what the Puranas had to say on the subject of killing females at birth. ${ }^{36}$ In a tract of approximately 14,500 words, less than 1,500 words were expended on the religious 
arguments against female infanticide. The remainder of the tract is tuned to the much favoured Enlightenment ideals of privileging proof and rigorous reasoning. Daji introduced unambiguous arguments against female infanticide on several grounds that included firstly, the 'protection of our offspring is the most sacred of all of our obligations' and secondly, that any abrogation of the first rule is 'treason against the Divine authority.' That the supreme authority of determining the life span of any living creature is solely by the "moral government of the Deity' and not by Man is proposed by Daji as a strong argument against taking matters of life into human hands. Daji took care to avoid pinpointing the religious background of God and instead used neutral terms to designate God as the 'Deity'. The third reason allowed Daji to enter into the 'social compact' (contract) of all societies. The duties of every infant toward his or her country, and to humankind were stilled at birth by female infanticide at one shot, terminating the societal claims on the child. Daji was shrewd enough to point out that a person who murdered his own daughter could not be trusted 'in social life as a citizen of a state', as affairs of government demanded a strongly developed sense of justice and social awareness. ${ }^{37}$ The proud Jadeja who prized his freedom and self-governance, he felt, would be subdued, if not struck down, by this argument.

In outlining the fourth reason, Daji entered into a debate with the Jadejas regarding ideas of manliness and masculinity and the way of the warrior - the Kshatriyas. Societal organisation in India was arranged on the basis of part endogamous relationships between groups and part hereditary occupations called the 'caste' system. Deeply hierarchical the social grouping at the top were Brahmins (priestly occupations) and Kshatriyas (to which caste the Rajputs/Jadejas belonged) were distinguished by soldiering and protecting his master with loyalty. ${ }^{38}$ Constant involvement in war and conquest had given them the aura of courage and manliness. Daji questioned their idea of manliness. A child, he explained 'is the very image of innocence, helplessness and amiability' and to murder it is not courage but, an act of a 'coward'. Only a society that could not distinguish between 'right and wrong, truth and falsehood, good and evil' he expounded, could indulge in such heinous actions. It is worth quoting Daji on the very bold arguments he made about Rajput stereotypes of manliness and the way of the Kshatriya (warrior caste):

Many unthinking Jadejas will perhaps be ready to say: 'we are Kshatris; we are brave; our business is to fight and to wield the sword, Puranas, Shastras and Vedas are good for 
weak Brahmans, and pity (pretty) fit for Baniyas (mercantile caste). Our business is to slay; talk to us about slaying and we listen to you. Do not mention what the Bhagavat and other Puranas say about Infanticide. All that you have said is quite true, but female infanticide is necessary to uphold our Kshatryism (way of the warrior)." ${ }^{39}$

The last line of the quote brings us to the heart of the reasoning process employed by Daji. The main task of Daji was to unpick the maxim of Rajputs that 'female infanticide is necessary to uphold our Kshatryism.' Daji challenged their ideas of manhood and manliness by quarrying deeper into their notions of masculinity. Keeping with this strategy of deconstructing their ideas on the warrior's responsibilities, Daji outlined the duties of Kshatris (warriors) by pointing out that their main duty was to 'protect and not destroy' lives; 'to support religion' and not contaminate it. The next few arguments were designed to evoke strong feelings of outrage in the Jadejas when Daji argued that their prowess was nothing much compared to the mighty kings of the Lunar (Chandravamshi) and Solar (Somavamshi) races and yet, the latter did not kill their female infants. 'Pride and purse' as many scholars have pointed out were the key arguments of Rajputs to sustain the custom of killing female infants but in Daji's tract we see a wholehearted attempt to smash this argument. He pointed out to the Jadejas that they were lower in rank than the highest of their race - that the other Sasodias, Rahtores and Paramars were higher than them. Continuing the same line of thought he asked them in a combative tone: 'Then how could they possess so much pride than even such great men as these? Whence do you derive that pride?' The language of the discourse hit the right spot in Rajput 'pride' when he insulted them about this 'strange kind of Kshatryism' that demanded slaughter of girl children. 'They who have conquered you one after another? Have they not more real cause for pride, than you...' argued Daji firing the final arrow in his argument that if the legitimate source of pride lay in warrior cults then the victorious Maratha, Muslim and English warriors all had better claims on it.

In the fifth rationale he outlined, Daji turned to an equally important reason that early Company officials had written about regarding the economic motives of the Jadejas in their decision to terminate female lives. The lavish display of wealth and enormous expenditure of money on a daughter's wedding had been cited as a reason for the custom but Daji pointed out that it was not the daughter who created the situation but greedy Brahmin priests who demanded unrealistic rituals based on money alone. That the human instinct of protection and 
nurture had been thwarted in the Jadejas by 'rupees, annas and pies' ${ }^{90}$ was highlighted in great detail by Daji. Whether it was 'purse' or 'pride' Daji's arguments fitted in neatly with the post-Mutiny rhetoric of British rule. By disparaging the masculinity of the Rajputs and by boldly outlining their loss of self-esteem in losing out to, first the Muslim, and then, to British rulers, Daji was signalling the Jadeja communities to obey the new rulers and follow the path of social and moral order set out by them. These ideas had strong resonance with the Select Committee judging the competition and it helps to explain why Daji's essay stood out amongst the contenders.

\section{IMPLICATING THE MOTHER: JUSTICE AND GENDER IN THE 'MOLECULAR DISCOURSE' OF BHAU DAJI}

This section utilises the linguistic concept of the 'molecular structure of discourse' ${ }^{41}$ filtered through the colonial frame, to deconstruct Bhau Daji's essay and unravel the process by which indigenous men became collaborators in the 'discovery' of the crime and how the state itself moved its strategies of rule from coercion to persuasion through the prize culture. The literary theorist Gauri Vishwanathan has demonstrated how the establishment of English Literature as a discipline in the Indian curriculum allowed for an easy and voluntary cultural assimilation of an emerging educated elite in colonial India. ${ }^{42}$ Although the details of the kind of curriculum Indian elites studied and the replacement of indigenous canonical texts by English classics still awaits further study, by the mid-nineteenth century, the edifice of traditional literary criticism in India was erased gradually and European genres were introduced, of which the most well-researched genre is the novel. Oral transmission of a shared past was predominant in indigenous traditions of communication - the epic poem, the Bakhars (chronicles of kings), the ovi (a metrical composition in religious hymns). These were literary storehouses of successive stages in Indian history. The nineteenth-century brought European ideas of what constituted the most appropriate genres. The 'natural leaders' and successive generations of English-educated middle-classes were propelled into adopting the new styles of literary criticism and thus the indigenous genius was yoked to the rule of European genres. ${ }^{43}$ Paul Hernadi is right in his observation that the "convention trained expectations of the reading public shape the writer's 'formative intentions', ${ }^{44}$ The prize essays may be gauged as a repository of literary devices tailor-made by the colonial state and utilised by the natural leaders in the service of the imperial state. 
In nineteenth-century Europe, the 'essay' as a mode of communication had rapidly gained a reputation for being an objective tool that projected reality. Georg Lukacs himself opined and concretised this observation by arguing in 1911, that the writer's incessant search for a system of values lends itself to the generic form of the essay as it relies on the process of evaluation rather than on the verdicts eventually passed on it. ${ }^{45}$ If the essay was a 'specialized and relatively late form of literary persuasion, ${ }^{46}$ then why, and how, did the Indian reformers adapt to this new genre? And how was this manifested in the debates on female infanticide? Did they discard older and more indigenous forms of communication such as the dialogue-based debate form? The linguists Scholes and Klaus have termed the narration and description aspects of the essay format as the 'molecular structure of discourse.' The allures of this literary device for Daji were many, and not least the idea that, he could sway the reader's opinions towards the fitness of his arguments against female infanticide. Daji explained the uses of 'persuasion' in the 'Preface'. He clarified that the Jadejas were convinced of 'the impropriety of Infanticide, but not of its enormity' and hence, his objective was to demonstrate to them the brutality of it and in doing so, "persuade them to relinquish it. ${ }^{47}$ As the Judge of the prize committee revealed in a somewhat exasperated note:

The writer is of opinion that without exposing these excuses, little progress can be made, either in convincing them of the heinousness of the crime, or in persuading them to desist from it. He has also taken the liberty of writing the essay in the form of an address, which method, he conceives, is best calculated to promote the views of Government inasmuch as an appeal to their feelings, religious and moral, could not well be shaped in a book-like form, and if introduced, would have lost much of its effect. ${ }^{48}$

In the essay the reader and author are the only characters because the essay is the most utilitarian form of direct literary address. In essays, words are used to convey ideas and feelings too but in an essay, there is also a 'rhetorical situation', wherein words are directly addressed to the reader, therefore "persuasion" comes into play. Daji had clearly understood the power of the essay in persuading the erring Rajput communities, and hence he started the essay with a powerful lecture to them in the first person calling them 'Friends and Countrymen', thus identifying himself as a fellow Indian.

Safe in the knowledge that he had the backing of the government, Daji tried to win over the hearts and minds of Indians through a softer approach to preventing the practice of 
female infanticide. We must remember that the mid-nineteenth century was a period in which early nationalist activities were taking place in major towns and cities with the formation of elite associations who wooed the Raj for resources especially for employment. Mindful of these pulls and pressures of the aspiring Indian classes, Daji's essay is comparable to a carefully crafted government mouthpiece when he said that 'Argument and reasoning must go hand in hand with the force of law. ${ }^{49}$ Prize winning essays are littered with praise of the government as seen in Daji's pronouncements on how 'A combination of extraordinary circumstances has placed the destinies of India in the hands of the British. Through it the tyranny of a thousand years has been pulled down and peace and tranquillity spread throughout the length and breadth of Hindustan. ${ }^{50}$ Initiatives such as the introduction of native competitions to construct the best essay against female infanticide were designed, he explained, to 'go hand in hand with the law', and that 'it is only by the diffusion of knowledge, not by force...that these errors of judgement can be thoroughly removed ... ${ }^{, 51}$ These descriptions served to reinforce the notion of native leadership support for the British actions in India and ensured that the British were perceived as acting out of genuine humanitarian concern and support for the Indian people themselves. They also epitomised the reforming strategy of their day; that of a 'spirit of cooperation' between the British and indigenous men who were products of the Enlightenment bestowed upon India by the British and together they were propelling India on a modernising track. ${ }^{52}$

Daji's tract incorporated the idea that the new rulers came armed with tools of modernity such as 'justice' for its subjects of the vast far flung colonies. The term 'justice' is riddled with controversy with scholars from varied disciplines arguing that justice can be evoked on ethical, religious, gender or legal principles whilst newer scholarship has queried the binarism embedded in mainstream theories on justice. ${ }^{53}$ Older forms of legal systems such as the ones which developed in European jurisprudence were embedded in the idea that the ultimate arbiter of justice is the Divine Force - known as God to laity. ${ }^{54}$ Daji invoked the Divine concept of 'justice' arguing against the Western Indian communities such as the Minas who attributed female infanticide as enjoined by Divine authority. Calling on 'God' as 'the invariable fountain of Justice', Daji contended that nowhere in the vast compendium of Hindu holy books could one find divine sanction for the act of female infanticide. ${ }^{55}$ On the contrary, he argued that if God had willed the Minas to be shorn of the responsibility of rearing daughters then he would not have created female foetuses, and that if by chance a female infant was born, God would have dried up the mother's breast of milk. Since such 
extraordinary events had not occurred, it could safely be pronounced that God's justice had prevailed on the birth rather than the extermination of female infants. The idea of justness in society, he attributed, like a typical Enlightenment-influenced scholar, to granting Man agency to act and freedom to will that went beyond seeking or legitimating evil practices by invoking hereditary custom; immemorial tradition or adducing Divine authority for it. ${ }^{56}$ In a brilliant manoeuvre, Daji addressed the Jadejas by comparing Thuggee (ritualised murder of travellers) to Female Infanticide. He argued cogently that Thugs too sought customary sanction for committing horrendous crimes but asked would the Jadejas allow Thuggee in their territories? By this logic, Daji demolished grounds on which the Rajputs sought sanction for the custom of female infanticide. Divine justice, he argued would not pardon or excuse Jadejas on grounds of custom, tradition and man-made laws that abrogated life chances.

Daji was not a passive collaborator with the Raj. He had resisted the British government's desire for an essay that 'took no assistance from Hinduism. ${ }^{57}$ For this reason alone, the Prize Committee members were divided on their opinion about his essay. A missionary by calling, Reverend G. Piggott in the Committee, expressed hesitancy in recommending it due to Daji's use of Hindu frame of argumentation. Piggott's assent was obtained by modifying the original title and convincing Daji to revise some of the content. For example, the original title before it was published and chosen by Daji read as: "Infanticide shall be condemned to the Hall called 'Tamisra." "58 The term 'Tamisra' is a wonderfully evocative Hindu metaphor for 'Hell'. Members like Piggott expressed disquiet that Daji had so boldly evoked the idea that Hinduism as a religion neither believed nor advocated the killing of female babies. Instead, unanimity of opinion was sought for placing Daji's essay at the top of the pile by changing the title to a neutral sounding 'An Essay on Female Infanticide'.

Daji's nuanced collaboration with the Raj can be gauged from the substance of the tract. He masterfully blended the genres of legend and myth skilfully with contemporary issues. In pursuit of persuading the Jadejas of the wrongfulness of their acts in killing female infants, Daji related his own version of a well-known tale in Gujarat about a demon tree which beckoned weary travellers with its lush foliage. But the care-worn traveller who lay under its branches went into a delirium and never woke up. Soon a Yaksha (demi-god) descended from heaven and armed with his notion of justice, knowledge and good nature stationed himself near the tree, warning all passers-by to avoid the tree's menacing embrace. ${ }^{59}$ Those who heeded the Djinn's advice became prosperous, and those who didn't 
were ruined. And, so the tale ended. These friendly spirits were evoked in popular imagination during harsh times in colonial days for their qualities of 'punya-jana' or 'good people'. Daji's invocation of the good djinns subtly takes advantage of the popular knowledge. ${ }^{60}$ It is interesting that at this point, Daji deviated from the legend and inserted his voice thus:

The name of this tree is Infanticide. The two roads are those that lead to Kathiawar and Kutch. The travellers are the Jadeja Rajputs who reside in those countries, and the Yaksha is the British Government, whose humane attempts to root out the evil practice, obtain the approbation of the civilized world. ${ }^{61}$

In the moral of this tale, Daji was clearly pointing to the arbitration of justice by the 'demiGod', namely the Raj, and spoke of 'penalties which will surely follow' for those who did not. After trying out the approach of persuasion, Daji was not averse to pointing out how coercion may follow if the Rajputs did not heed the voice of the new government in India.

Finally, we need to probe Daji's perspectives on the culprit in the crime of female infanticide in Gujarat. Radhika Singha has identified the 1830s as the post-pacification phase of British encounter with infanticide. She has argued that 'magisterial authority locked in a struggle with the male head of the household over the terms on which rank and patriarchal right could coexist with colonial rule'. ${ }^{62}$ In addition, the early Company State had ruled that the punishment of certain offences was best left to the community or to the "head of the household.' Singha has conjectured quite rightly that this strategy of the Company harmonised with the aspiration to maintain order, not only through the institutions of law and policing, but officers conducting 'searches for violations of the abkari (revenue) regulations were prohibited from entering the zenana in houses belonging to persons of respectability and credit; that is, of all those classes whose women do not ordinarily appear in public., ${ }^{63}$

The Jadejas' right to manage their own domestic arrangements were eroded gradually by the state when it clashed with its own fiscal or ideological imperatives. Increasingly the Company state adopted a belligerent attitude urging Rajput communities to renounce marital strategies for social mobility and rank which it held to be both homicidal and monetarily disastrous. Bhatnagar, Dube and Dube suggest that the British did not to intervene in the affairs of the high class Rajput mothers in North West Provinces because they were zenanabound and hence out of the grasp of the state but more significantly they were actually 
regarded as natural allies of the state. ${ }^{64}$ This is corroborated by Pakrasi who has argued that British looked to the 'humanity and tenderness' of the Rajput women to persuade their husbands against the practice. ${ }^{65}$ However, reports sent regularly by officials on-the-ground from Central India and Kathiawar did not corroborate with the Victorian ideology of femininity now heaped upon Rajput women. Colonel Walker's report on the other hand, stated that Jadeja men implicated their women saying 'it was an affair of the women; it belonged to the nursery, and made no part of the business of the men. ${ }^{66}$ This suggested that the state was aware of women's roles but had no extensive proof of it, nor did it want to believe that such was the case in India. The substantive evidence was provided by indigenous reformers through the prize cultures. As Daji's prize essay demonstrated, the Jadeja mothers from Kutch and Kathiawar, were attributed with a great deal of power and direct involvement in female infanticide. Daji explained that '...some [mothers] do not wait for the mandate of their husbands, but of their own accord bereave of life the infant which but a few moments before they had brought into the world' ${ }^{67}$ In an interesting twist, Daji whilst outlining the mode of execution of infants, considered the role of midwives as merely instrumental, arguing that they indulged in such vile acts 'for the love of money, and nothing else... ${ }^{68}$ The weighty and censorious language directed towards native wives and mothers is enlightening in the quest to try and piece together the culprits of female infanticide with the broader reality of the situation.

One has to ask the question as to what extent the representations of women's agency in the crime was determined by the imperatives of the prize culture itself. In 1835, Captain Jacob, the Political Agent in Kathiawar who knew very well the fragile nature of Company rule in Western India, had expressed serious reservations against intrusive policies into the domestic arena of the Rajputs. He was anxious about creating ill-will by 'perpetual and harsh inquisition into the domestic affairs of a proud tribe... and the difficulties of getting evidence in a crime that was conducted in great secrecy within the home. ${ }^{69}$ Instead, he advocated the persuasion method through education and the institution of the prize culture by setting aside a sum of Rs.1000 for the purpose. If detection of the crime was made largely impossible for the British officials because Rajput women remained 'largely invisible', educated indigenous men could be brought into the colonial circuits to conduct the investigations. ${ }^{70}$ These educated reformers were in possession of considerable data which contradicted the colonial depiction of absolute female subordination in the infanticidal clans. Daji fulfilled this expectation by outlining how humanity and tender feelings that are supposed to be first nature 
to a wife and mother had disappeared in Rajput women. ${ }^{71} \mathrm{He}$ went further by comparing Rajput women to the most 'savage' tribes of Africa and South Sea Islands, where he argued mothers alone were the perpetrators of the crime. ${ }^{72}$ It is well-known in imperial studies that not only was the nineteenth-century the 'high noon' of empire but it was also an era wherein European empire-builders fed on Enlightenment principles had carried out multi-pronged crusades against non-Christian religions and affirmed their own conception of progress in far flung colonies. Daji as a nineteenth-century product of this negotiation with empire, found it convenient to examine the nature of Rajput womanhood as a unit of analysis for evaluating progress or backwardness in arriving at an understanding of the achievements of that community and found it wanting. By condemning Rajput mothers for holding back Jadeja civilisation he had made Britain's careful tutoring an urgent necessity over these unruly and wild peoples at a time when Company governance was nebulous in these territories. Prize cultures, thus became a crucial instrument for the legitimation of the further conquest of India.

\section{POSTSCRIPT: PRIZE CULTURE AS A 'PUBLIC RELATIONS ENTERPRISE'73 BY THE COMPANY RAJ}

The soft approach embodied in prize cultures through the incentives of essay competitions, educating the natives and a system of rewards by the early colonial state had far reaching consequences. The palliative methods even as they seemed gentle and persuasive in comparison to coercive techniques, were actually quite violent in gendering the practice of female infanticide. It resulted in shifting focus from a community-specific 'custom' of female infanticide which had held 'heads of households' accountable for it to understanding female infanticide as a 'crime' committed by women (principally mothers and midwives).”Arguably, the British had not made an entirely new discovery but instead the time was now ripe for the 'official' discovery of the female criminal and may be considered as a precursor for the retributive justice embedded in the future Infanticide Act of 1870. The singling out of the infanticidal woman as the sole perpetrator of the crime served several functions: it allowed Indian patriarchal arrangements to retrench themselves whilst protecting the heads of households from attack, calumny and imprisonment. For the colonial state, it helped to redefine the power relations of the colonizer and the colonized through the formation of a formidable body of knowledge about depraved Indian female sexuality that could be deployed in claims of rule. As long as the Indian woman was a total victim she could only be 
protected with restorative justice but when identified as a criminal with proof, retributive justice could be applied successfully. Harnessing the productive husbandry of Rajput communities could now go on hand in hand with the peaceful and regular exactions of revenues without the complaints of dowry and marriage expenses hindering the revenue machinery of the colonial state. Thus, it was only by the middle of the nineteenth century that the British could act on information that women were not mere 'victims' in relation to the killing of infant children.

Certainly, the prize cultures had a large part to play in the changing fortunes of Rajput families - both men and women. If the British had wanted a reason to directly intervene before the 1870 Act, involvement of women in female infanticide provided an unswerving path for them to follow. However, the purpose of the consideration of infanticide and the establishment of the female crime is to corroborate the argument that the British were selective and careful in their approach to both the needs of governance and the imperatives of the 'civilising mission'. The early Raj was not yet stabilised in Gujarat and parts of Maharashtra by the 1830s and 40s and they needed indigenous allies to proclaim what it knew rather than pronouncing it themselves. The prize culture acted as an instrument of rule providing patronage to the right kind of 'natural leaders' ${ }^{74}$ Awarding prizes to essays that reflected Enlightenment-based value systems and thwarted Indian ambitions for selfgovernment was a key system of symbolic give-and take in order to build the 'right kind of allies' for the Raj. Conversely, essays that did not follow this pattern were viewed with disdain and contempt. The Company Raj sponsored essay competitions continuously all over India in the hope of a public relations exercise which linked the right type of "natural leaders' to their communities. As we have seen, the Prize Committees also pointed to this prerequisite wherein the members were either holders of state office in the elaborate machinery of the Company government or were intimately connected to it. The careful and sober orchestration of the prize culture by the Company government were thus guided by cultural as much as material and political needs of the state in early and mid-nineteenth century India. 


\section{NOTES}

${ }^{1}$ A summative assessment of the impact of the civilising mission in fields as diverse as law, sports and medicine is in Harald Fischer-Tiné and Michael Mann, (eds) Colonialism as Civilizing Mission: Cultural Ideology in British India (London, 2004).

${ }^{2}$ Kanti B. Pakrasi, Female Infanticide in India, (Calcutta, 1970); Lalitha Panigrahi, British Social Policy and Female Infanticide (New Delhi, 1972).

${ }^{3}$ Veena T. Oldenburg, Dowry Murder: The Imperial Origins of a Cultural Crime (Oxford, 2002), p. 41.

${ }^{4}$ Alice Clark, 'Limitations on Female Life Chances in Rural Central Gujarat' in Indian Economic Social and History Review, 20:1 (1983), p. 8.

${ }^{5}$ Rashmi D. Bhatnagar et.al. Female Infanticide in India A Feminist Cultural History (Albany, 2005).

${ }^{6}$ Padma Anagol, 'The Emergence of the Female Criminal in India: Infanticide and Survival under the Raj', History Workshop Journal, Spring (2002), vol. 53, pp. 73-93.

${ }^{7}$ Malavika Kasturi, 'Law and Crime in India: British Policy and the Female Infanticide Act of 1870' in Indian Journal of Gender Studies, 1 (1994), pp. 169-193; Radhika Singha, 'Colonial Law and Infrastructural Power: Reconstructing Community, Locating the Female Subject' Studies in History, 19 (2003), pp. 87-126.

${ }^{8}$ Chris A. Bayly, Empire and Information: Intelligence Gathering and Social

Communication in India, 1780-1870 (Cambridge, 2005).

${ }^{9}$ The 'natural leaders' concept entered modern Indian history works in the 1970s. See the thoughtful works of Francis Robinson, 'Consultation and Control: The United Provinces' Government and Its Allies, 1860-1906', Modern Asian Studies, 5:4 (1971), pp. 313-36. Also, Chris Bayly, 'Local Control in Indian Towns - the case of Allahabad 1880-1920', Modern Asian Studies, 5:1, (1971), pp. 289-311.

${ }^{10}$ James F. English, The Economy of Prestige: Prizes, Awards and the Circulation of Cultural Value (Cambridge, 2005)

${ }^{11}$ English, The Economy of Prestige, p. 37.

${ }^{12}$ Pakrasi, Female Infanticide in India, pp.77-214. 
${ }^{13}$ See Reports, Memorandums and Correspondences of Colonel Alexander Walker et.al in Colonel Alexander Walker and J.P. Willoughby, Measures adopted for the Suppression of Female Infanticide in the province of Kattywar, \&c. Selections from the Records of the Bombay Government, No.XXXIX, (Part Two), (Bombay: Education Society Press, 1856). Henceforth Selections. (Maharashtra State Archives, Mumbai, India), henceforth MSA. ${ }^{14}$ From J. P. Willoughby, Political Agent, Kattywar, to C. Norris, Chief Secretary to Government, Bombay, 24th September 1834, J.P. Willoughby to C. Norris, Chief Secretary, Bombay Government, 24 September 1834, submitting observations on female infanticide, Selections, pp. 441- 457. MSA.

${ }^{15}$ Letter from J.P. Willoughby, 12 April 1835, Selections, p. 467. MSA.

${ }^{16}$ Ibid. p. 443. MSA.

${ }^{17}$ Letter from James Erskine, Political Agent in Kattywar, 30 June 1837, with Reports on Female Infanticide for the years 1835 and 1836, Selections, p. 516; p.517; and p.532. MSA. ${ }^{18}$ Ibid. pp.493-536. MSA.

${ }^{19}$ Paras 9 to 11. A Proclamation by the British Government, APPENDIX B, James Erskine, Political Agent. Kattywar, 30th June 1837, Selections, pp.539-541, MSA.

${ }^{20}$ Letter from Captain G. LeGrand Jacob, Acting Political Agent, Kattywar, 23 October 1841, to J. P. Willoughby, Chief Secretary, to Bombay Government, Selections, p.601. MSA.

${ }^{21}$ Ibid., 602-3. MSA.

${ }^{22}$ Memorandum by J.P. Willoughby, Secretary to Bombay Government, 1 June 1842, Para 18, Selections, pp. 621. MSA.

23 'Notification: Prize essays against the Practice of Infanticide' C. Morehead, Secretary to the Board of Education, $12^{\text {th }}$ Sept. 1843, Selections, p. 637. MSA.

${ }^{24}$ Ernest Bender, Review of 'Writings and Speeches of Dr. Bhau Daji', (ed.) T.G. Mainkar, in Journal of American Oriental Society 98:2 (1978), p. 336.

${ }^{25}$ T.G. Mainkar, R. G. Bhandharkar, M.N.Dhar, (eds) Writings and Speeches of Dr. Bhau Daji, (Bombay, 1974).

26 'Bhau Daji, Dr.,' by N.B. Wagle, Encyclopaedia Britannica Vol.1, (Cambridge, 1911) $11^{\text {th }}$ edn., p. 845 .

${ }^{27}$ Pakrasi, Female Infanticide in India, p.193.

${ }^{28}$ A larger chapter including all prize winning essays on infanticide and female infanticide covering the regions of Punjab, United Provinces, Maharashtra and Gujarat will appear in my forthcoming book, 'Prize Cultures and Cultural Imperialism in Colonial India'. 
${ }^{29}$ James Mill, History of British India, (London, 1818), Vol.1, p.115.

${ }^{30}$ The Committee that adjudicated Bhau Daji's round of essays consisted of: E.H. Townsend, Secretary to the Government in the Revenue Department; Reverend G. Piggott, Secretary to the Bombay Education Society; C. Morehead Secretary to the Board of Education. See margins of the Letter by J. P. Willoughby, Chief Secretary to Government. Bombay, 20th November 1844 to C. Morehead, Secretary to the Board of Education, Selections, pp. 639. MSA.

${ }^{31}$ I have not been able to trace the original essays that were rejected but wholesale extracts and summaries of these essays and the decisions of the judges are reproduced in D.D. Wilson's remarkable source titled as History of the Suppression of Infanticide in Western India under the Govt. of Bombay including Notices of the Provinces and Tribes in which the practice has prevailed, (Bombay, year unknown), pp. 331-3.

${ }^{32}$ Daniel J.R. Grey, “Creating the 'Problem Hindu': Sati, Thuggee and Female Infanticide in India, 1800-60”, Gender and History, 25:3, (2013), p. 498.

${ }^{33}$ Wilson, History, footnote on p. 230.

${ }^{34}$ Uday Singh Mehta, Liberalism and Empire: Nineteenth Century British Liberal Thought, (Chicago, 1999), pp. 69.

${ }^{35}$ Bhawoo Dajee, An Essay on Female Infanticide, 1844, (Bombay, 1847), pp. 1-3.

${ }^{36}$ Michael S. Dodson, Orientalism, Empire, and National Culture: India, 1770-1880, (New York, 2007).

${ }^{37}$ Ibid., p.6.

${ }^{38}$ For the origins of the caste system and the place of Kshatriyas see Gavin Flood, An Introduction to Hinduism, (Cambridge, 1996).

${ }^{39}$ Ibid., p. 13.

${ }^{40}$ Ibid, p.15. 'Rupees, annas and pices' are Indian units of currency.

${ }^{41}$ Robert Scholes \& Carl H. Klaus, Elements of the Essay, (Oxford, 1969),

${ }^{42}$ Gauri Vishwanathan, Masks of Conquest: Literary Study under British rule, (Columbia, UP, 1989).

${ }^{43}$ Tom Metcalf has argued that the highly selective process by which certain groups were identified as links between the government and the people also led to divisions of interests in and intra-group competition. See Ideologies of the Raj, (Cambridge, 1994), pp.186-87.

${ }^{44}$ Paul Hernadi, Beyond Genre: New Directions in Literary Classification, (Ithaca, 1972), p. 116. 
${ }^{45}$ Georg Lukacs cited in Hernadi, Beyond Genre, pp.15, ff.38

${ }^{46}$ Hernadi, Beyond Genre, p. 150.

${ }^{47}$ Dajee, An Essay, 'Preface', unpaginated.

${ }^{48}$ Ibid.,

${ }^{49}$ Dajee, B., An Essay on Female Infanticide, 'Introductory Observations' p. ii.

${ }^{50}$ Ibid., p. ii.

${ }^{51}$ Ibid., p. ii.

52 Anagol, 'Emergence of the Female Criminal', p.77

${ }^{53}$ Amartya Sen, The Idea of Justice, (Cambridge MA, 2009).

${ }^{54}$ Brian Barry, Theories of Justice (Berkeley, 1989); Harry Brighouse, Justice (Cambridge, 2004).

${ }^{55}$ Dajee, B., An Essay on Female Infanticide, pp.18-19.

${ }^{56}$ Ibid., p.18.

${ }^{57}$ Dajee, An Essay, 'Preface', unpaginated.

${ }^{58}$ See Letter by J. P. Willoughby, Chief Secretary to Government. Bombay, 20th November 1844 to C. Morehead, Secretary to the Board of Education, Selections from the Records, pp. 639. MSA.

${ }^{59}$ In Hindu mythology, 'Yaksha' is defined as 'A class of semi-divine supernatural beings closely associated with natural phenomena, especially vegetation and trees.' William Johnson, W. J. Johnson, A Dictionary of Hinduism, (Oxford, 2009), p.277.

http://www.oxfordreference.com.abc.cardiff.ac.uk/view

${ }^{60}$ For this attribute of the supernatural being, see John Dowson, A Classical Dictionary of Hindu Religion, Mythology, Geography, History and Literature, (London, 1928) $6^{\text {th }}$ edn. p.373.

${ }^{61}$ Dajee, An Essay, pp. 21-22

${ }^{62}$ Radhika Singha, 'Making the domestic more domestic: Criminal law and the "head of the household”, 1772-1843', Indian Economic \& Social History Review 33: 1996, p.312.

${ }^{63}$ Ibid., pp. 314-5.

${ }^{64}$ Rashmi Bhatnagar et.al., Female Infanticide in India p. 151.

${ }^{65}$ Pakrasi, Female Infanticide, p. 43.

${ }^{66}$ Letter from Lieutenant Colonel A. Walker, Resident at Baroda, To the Honourable Jonathan Duncan, Governor of Bombay. Para 65, 15th March 1808. Selections, p.328. ${ }^{67}$ Dajee, An Essay, p. 7. 
${ }^{68}$ Ibid., p. 17.

${ }^{69}$ Major Jacob's report cited at length in Wilson, History of Suppression, pp. 262-72.

${ }^{70}$ Kasturi, 'Female Infanticide: Selections from the Records of the Government of the NorthWestern Provinces, Second Series, Volume VIII, Allahabad, 1871' in Indian Journal of Gender Studies 7 (2000), p.127.

${ }^{71}$ Dajee, p. 7

${ }^{72}$ Ibid, pp.10-11.

${ }^{73}$ The term is borrowed from English, The Economy of Prestige, p. 31.

${ }^{74}$ An excellent case study of how Gujarati communities were appeased and elected in the urban politics of Surat is in Douglas E. Haynes, Rhetoric and Ritual in Colonial India, (Berkeley, 1991), pp.101-114. 